\title{
Adenosarcoma Clinical Distant Metastasis TNM Finding v7
}

National Cancer Institute

\section{Source}

National Cancer Institute. Adenosarcoma Clinical Distant Metastasis TNM Finding v7. NCI Thesaurus. Code C89629.

A clinical finding about one or more characteristics of adenosarcoma, following the rules of the TNM AJCC v7 classification system as they pertain to distant metastases. (from AJCC 7th Ed.) 